\title{
Chapter 12 \\ Water Governance Futures in South Asia \\ and Southern Africa: Déjà Vu All Over Again?
}

\author{
Douglas J. Merrey, Anjal Prakash, Larry Swatuk, Inga Jacobs, \\ and Vishal Narain
}

\begin{abstract}
This chapter explores the likely trends and outcomes in water governance by about 2030 in two regions: South Asia and Southern Africa. It addresses the question: What are the prospects for developing governance arrangements in the two regions that will lead to more positive outcomes in terms of sustainably improving people's livelihoods while conserving natural resources? It examines this question through three "lenses": (1) "beyond disciplines", (2) "beyond scales" and (3) "beyond 'institutional' hardware to 'human' software". The two regions are currently on different trajectories: the Southern African trajectory seems to be moving in a positive direction, in contrast with South Asia. The chapter discusses four factors that go far to explaining this divergence: (1) the contrasting roles of the hegemonic countries, (2) the level of intercountry "trust" that has emerged in the two regions, (3) the roles of civil society and NGOs and (4) the roles of external facilitators. The chapter emphasises the importance of developing the human software the "soft skills" of communication and shared values complementing technical competence - as the most critical driver of successful water resource governance.
\end{abstract}

D.J. Merrey $(\square)$

Independent Consultant, Gainesville, FL, USA

e-mail: dougmerrey@gmail.com

A. Prakash

International Centre for Integrated Mountain Development (ICIMOD), Kathmandu, Nepal e-mail: anjal.prakash@icimod.org

L. Swatuk

University of Waterloo, Waterloo, ON, Canada

e-mail:1swatuk@uwaterloo.co

I. Jacobs

Council for Scientific and Industrial Research (CSIR), Pretoria, South Africa

e-mail: ingajacobs30@gmail.com

V. Narain

Management Development Institute (MDI), Gurgaon, India

e-mail: vishalnarain@mdi.ac.in 
Keywords South Asia $\bullet$ Southern Africa $\bullet$ Water governance $\bullet$ Transnational river basins $\bullet$ Problemsheds

\subsection{Introduction}

In the waning years of the past century and the early years of this twenty-first century, there have been predictions that competition for increasingly scarce water supplies will lead to famines, the breakdown of stressed societies, conflicts and even warfare among countries. Serious disagreements and threats are emerging over development of water resources. Water scarcity in North Africa and the Middle East threatens food security and economic growth ${ }^{1}$. Upstream countries on the Nile Basin want to replace water-sharing rules imposed by the colonial powers with new rules they deem more equitable - creating alarm and consternation in downstream countries for whom the Nile waters is critical (Swatuk 2012). In addition, the international consensus and drive behind the integrated water resource management (IWRM) paradigm is now fraying. IWRM has been the basis for considerable progress in increasing scientific knowledge and understanding of water resource issues, sharing this knowledge widely among stakeholders and building networks and institutions for managing water effectively (see, e.g. www.cap-net.org); but it has inhibited investments, especially in underdeveloped river basins such as those in Africa (e.g. Giordano and Shah 2014).

On the other hand, partly as a result of the IWRM movement, there are important signs that sharing water resources can trigger cooperation among countries (Wirkus 2005). The idea of sharing the benefits of water resource development rather than seeking formulas for equitable sharing of the water resource itself offers an opportunity to achieve a higher net benefit - but this requires a high degree of trust among the parties (Grey and Sadoff 2007; Sadoff and Grey 2002). This principle of "benefit sharing" is the basis for the Nile Basin Initiative, the Mekong Commission and the SADC Protocol on water sharing, among others (Earle et al. 2010). Achieving a high level of trust and creating effective institutional arrangements to produce and share the benefits equitably is fundamentally an issue of water governance. This is proving extremely difficult to achieve. The decade of progress made in achieving cooperation among most of the Mekong countries is threatened by unilateral investments in dams by some upstream countries eager to achieve more rapid economic growth (Burton 2011; Grumbine et al. 2012; Houba et al. 2013). The progress made by the Nile Basin Initiative (NBI) is threatened by disagreements over the fundamental rules for sharing water resources and by upstream countries hungry for rapid hydroelectric and agricultural development.

\footnotetext{
${ }^{1}$ See, e.g. http://www.un.org/apps/news/story.asp?NewsID =47181\#.Uw9h-aOYbIU (accessed 23 April 2014).
} 
The water sector does not exist in isolation: for instance, the understanding of the water-energy-food-climate change nexus has grown recently (Bizikova et al. 2013; WEF 2011). This reflects a growing recognition that the challenges posed within each of these "sectors" (for want of a better term) interact in complex and dynamic ways with the others. Further, governance and management arrangements for the water sectors are embedded in larger political and institutional contexts. Mobilising water for agricultural production and using it productively, particularly on rain-fed fields, will be critical for achieving future food security. However, mobilising water for hydroelectric and other uses is also critical in many regions - and both compete with the use of water for agriculture and support agricultural water by reducing energy costs of pumping. Climate change is affecting all major river basins in ways that are complex and not easily predicted. Making water available for drinking and household uses, ensuring adequate water flows for environmental services and improving the productivity of fisheries are other critical challenges.

Given these interlinkages and interdependencies, what will water governance look like in the future? By "future" we mean approximately 2030, on the premise that crystal balls and forecasting models become totally opaque beyond a 15-year horizon. Defining "governance" is difficult: there are multiple competing formulations. For the purpose of this chapter, we define governance as referring to "all processes of governing [i.e. managing affairs], whether undertaken by a government, market, or network, whether over a family, tribe, formal or informal organisation, or territory, and whether through laws, norms, power, or language". It relates to processes and decisions that seek to define actions, grant power and verify performance (Bevir 2013: 1). Most of those writings about "water governance" use the definition of the Global Water Partnership: "the range of political, social, economic and administrative systems that are in place to develop and manage water resources, and delivery of water services, at different levels of society" (Rogers and Hall 2003). Governance thus refers to the institutional systems and process through which decisions are made and implemented. It constitutes the processes through which control and authority are exercised in the allocation of water resources.

This chapter explores the likely trends and outcomes in water governance with a particular focus on cooperation and conflict over the management of water resources in two regions: South Asia and Southern Africa. In South Asia, the focus is on the governance of three very large-scale shared river basins, the Indus, Ganges and Brahmaputra, inhabited by nearly a billion mostly poor people. The Ganges and Indus basins are under growing stress in the context of a lack of appropriate water governance arrangements. South Asia has struggled to find ways to co-manage water resources to benefit everyone equitably in a context where there is much potential benefit to be achieved. Southern Africa is considered an example of relative success in developing ways to cooperate - but implementation is incredibly complex in systems that are smaller in terms of size and population but more water scarce than the South Asian basins. So the critical question is: what are the prospects for developing governance arrangements in the two regions that will lead to more positive outcomes in terms of sustainably improving people's livelihoods 
while conserving natural resources than achieved so far versus further deterioration and rising conflict?

We examine this question through three "lenses" which we characterise as "beyond disciplines", "beyond scales" and "beyond 'institutional' hardware to "human' software". Beyond disciplines addresses the question of how to mobilise the diverse types of expertise productively to solve problems. It is based on the recognition that no single discipline is sufficient to address the emerging challenges of water resource governance and management. Addressing the governance challenges facing the water sector requires a diverse range of scientific expertise combined with a wide spectrum of actors - represented by the state, civil society and the private sector. Further, no amount of technical and scientific ingenuity is adequate if the solutions generated are not relevant to the specific socio-political and socioeconomic contexts in which they are applied (Jacobs 2012).

Beyond scales examines how to define the "space" for transboundary water resource governance and management. Traditionally, there has been a tendency to prioritise the hydrological basin as the primary unit of analysis in water governance and its management. Recently, this notion has been broadened to include other socio-political and socio-economic communities with a stake in the resources: thinking has evolved from the watershed to the "problemshed" to the virtual and social basin (Mollinga et al. 2007). There is therefore a changing definition of international river basins - encompassing not hydrological boundaries alone but "lived in" social spaces, i.e. the sum of social practices and discourses that exist within the biophysical space.

The third lens, beyond institutional hardware to human software, enables us to examine the entry points to bring about a shift from institutional systems that favour the powerful at the expense of others, to more enlightened leadership and governance arrangements that can help achieve both greater social equity and environmental sustainability. The main focus of interventions, based on disciplines such as foreign relations, policy sciences and institutional economics, has been on engineering structural changes in institutions that change incentives and therefore behaviour and outcomes (North 1995). This emphasis may have led to a failure to recognise the equally critical importance of individuals" mindsets and "soft skills" in bringing about change: while training and capacity building has emphasised enhanced technical skills, less attention has gone to how to enable individuals to champion and lead in intangible areas like building trust and fostering norms that guide behaviour in more productive ways. This is not an either-or choice; rather it is a matter of getting the balance right between building institutions and fostering the soft skills needed to make them work.

The next two sections discuss the water governance challenges and opportunities facing South Asia and Southern Africa. Section 12.4 draws on the discussion in these sections and tries to assess the prospects for alternative futures and their implications for the well-being of the people. The concluding section briefly characterises the wider implications of these cases. 


\subsection{South Asia: A Glass (More Than) Half Empty?}

\subsubsection{The Emerging Water Governance Context}

Water governance in South Asia has changed dramatically in recent decades. The gap between governance and "government" has widened (Mathur 2009) as other actors have acquired stronger roles in the allocation of water resources. The locus of water policy-making has moved from the state to include other actors: partly through the dynamic of (formal and informal) markets, the private sector and civil society have created greater space for themselves (Narain et al. (2014)). State authority has been diluted at all levels. On the one hand, donors and funders play an increasing role in influencing the direction and nature of reforms; on the other hand, civil society organisations have also influenced water governance.

New discourses such as those of IWRM and neo-liberalism have penetrated the water sector. However, the regional relevance of the IWRM paradigm has been questioned, given both the apparent mismatch between the informal nature of the water economy and the emphasis on formal organisational structures envisaged under IWRM reforms and the lack of political edge in the way IWRM has been conceptualised (Kulkarni 2014; Mollinga et al. 2006; Shah and Van Koppen 2006). The neo-liberal paradigm has been criticised for its exclusion of the poor (Urs and Whittel 2009). The discourse on gender mainstreaming has gained prominence, even as the gap between rhetoric and practice has persisted (Kulkarni 2014; Joshi 2014; Ahmed 2008; Prakash et al. 2012).

During the 1980s and 1990s, disenchantment with the role of the state in the management of the region's massive surface irrigation schemes led to demands for a greater involvement of users in irrigation management. In South Asia, this process is referred to as "participatory irrigation management" (PIM). However, several factors limited the effectiveness of the process, including limited attention to issues of design and technology in the handover of irrigation systems, reproduction of unequal power relations in the internal working of water users' associations, limited attention to questions of rights and entitlements and powerful resistance within the bureaucracy (Narain 2008; Jairath 1999; Parthasarathy 1998). The debate on appropriate approaches to arrest groundwater depletion has continued, with "competitive deepening" identified as a major issue in some locations and climate change being recognised as another stressor, compounding the effects of groundwater depletion (Shah 2009, 2013). Falling water tables are seen as a serious threat to food security (Saleth 1996; Shah 2009, 2013).

South Asian water resource scholarship has thus recently experienced an upsurge (Mollinga 2008). Multiple voices are emerging in the water discourse; it is therefore necessary to create a space for dialogue among government, civil society and citizens (Lahiri-Dutt 2008; Narain et al. (2014)). In examining the opportunities for improved water governance and management, two scales are important: the growing potential for conflicts and cooperation across rural and urban uses and transboundary water conflicts, each of which is discussed below. 


\subsubsection{Rural-Urban Water Conflicts}

Most of the rapidly growing South Asia cities have expanded by acquiring the land and water resources of peripheral regions, creating vast peri-urban zones (Narain et al. 2013). Since urban expansion is a gradual process of acquiring land and water from the peripheral regions, it has equity implications for those living at the periphery of large cities, as it raises questions for their land and water security. The usurpation of peri-urban water sources in South Asian countries has taken many forms (Narain et al. 2013). First, there are physical flows of water from the peri-urban to urban locations, for instance, through water tankers or the construction of canals to divert water from rural to urban uses. Second is the acquisition of village common property water sources to build urban infrastructure. Third is the encroachment upon the village commons. The fourth is the pollution of peri-urban water sources by urban and industrial waste.

Several policy and institutional issues are responsible for this phenomenon. The first is the linking of land and water rights. When access to water is tied to ownership of land, the process of land acquisition that characterises urban expansion leads to loss of access to water sources as well (Narain 2014). The second is the fragmented nature of urban planning and rural development that presents rural and urban water supply as distinct planning entities. Urban planners and policy-makers focus on the expansion of urban water infrastructure, overlooking its implications for rural water security. There is growing conflict around peri-urban water sources both freshwater and wastewater (Gopakumar 2012; Narain 2014). The absence of appropriate forums or platforms for the integration of urban planning and rural development creates opportunities for conflicts over water, but there are also opportunities for cooperation. As urbanisation advances, the demand for platforms for negotiation and conflict resolution across rural and urban water supplies will become more visible.

An important water governance challenge in the region in the coming years will, therefore, be to develop appropriate institutions to integrate water supply provisions for urban and rural uses. This could take various forms: the evolution of multiple stakeholder platforms across rural and urban uses and the evolution of platforms to bring peri-urban residents face to face in dialogue with service providers. Current and on-going research in the region is expected to throw new light on opportunities for reducing conflict and encouraging cooperation in the management of peri-urban water insecurity.

\subsubsection{Conflict and Cooperation in Transboundary Water Resource Management}

The major transboundary rivers in South Asia are the Indus, Ganges and Brahmaputra. These rivers originate in the Hindu-Kush Himalayan region and are connected to the Tibet Autonomous Region of China. The Indus Basin connects Afghanistan, China, 


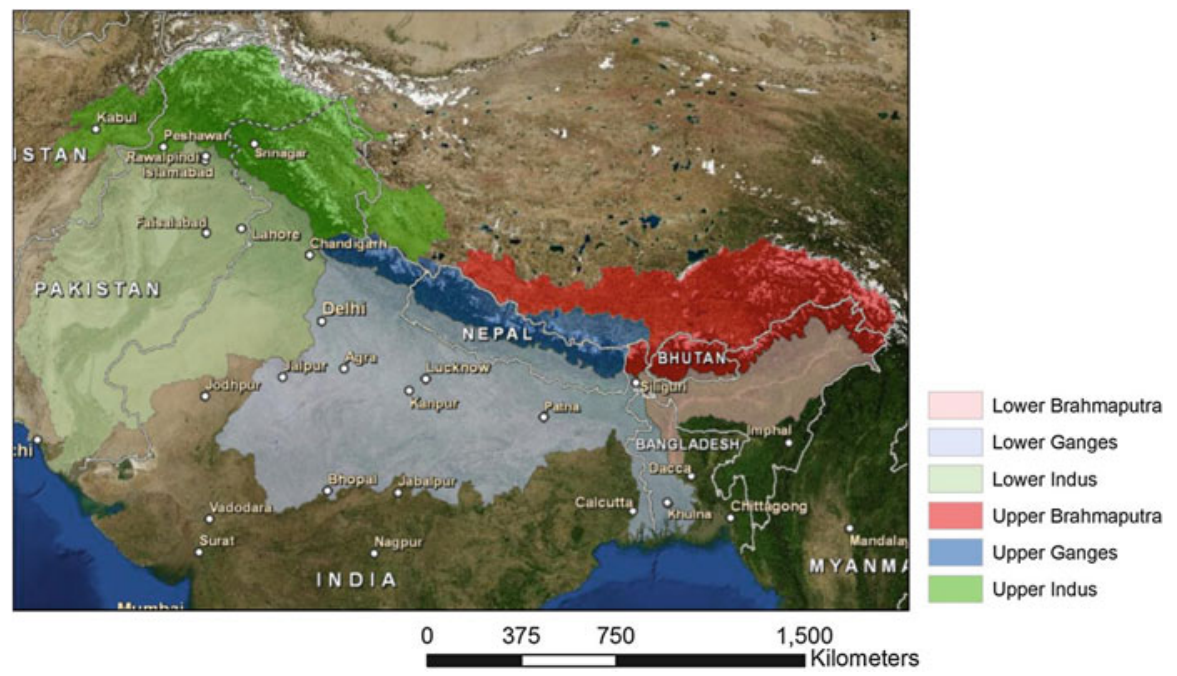

Fig. 12.1 Map of the Indus, the Ganges and the Brahmaputra rivers in South Asia (Source: Lutz and Immerzeel 2013)

India and Pakistan. Approximately 300 million people live in the Indus Basin, which covers an estimated area of 1.12 million $\mathrm{km}^{2}$. The Indus is critical to the survival of Pakistan, one of the driest countries in the world (Briscoe et al. 2005). The huge Ganges, Brahmaputra and Meghna (GBM) Basin system stretches across five countries: Bangladesh, Bhutan, China, India and Nepal (Ahmad et al. (2001)). While Bangladesh and India share all three basins, China shares only the Brahmaputra and Ganges, Nepal only the Ganges and Bhutan only the Brahmaputra. Nepal is located entirely in the Ganges Basin and Bhutan entirely in the Brahmaputra (Salehin et al. 2011). It is estimated that at least 630 million people live in the GBM river basin (Aquastat 2011) (see Fig. 12.1).

Worldwide, studies have shown that in modern times, no wars have as yet been fought over water and over 145 water-related treaties have been signed on transboundary rivers (Wolf 1998). Nevertheless, conflict over water at local levels is common and the potential for interstate conflict over water is real ${ }^{2}$. In South Asia, numerous challenges exist to managing the three major transboundary rivers (Prakash et al. (2013)). These challenges can broadly be divided into two, namely, biophysical and socio-political. On the biophysical side, Lutz and Immerzeel (2013) summarise the challenges in terms of cryospheric response to a changing climate in the Hindu-Kush Himalayan region. In essence, they conclude that the Indus runoff may change somewhat by 2050 (though the direction of change is uncertain), but the GBM runoff will not show major changes.

\footnotetext{
${ }^{2}$ See: http://pacinst.org/issues/water-and-conflict/ and http://www2.worldwater.org/conflict/timeline/ (accessed 8 September 2015).
} 
The real challenges lie in the socio-political arena where conflicts are brewing. The Indus Water Treaty has often been held as a showcase where the two signatories, India and Pakistan, had gone through two wars, but the Treaty has functioned reasonably well (Biswas 1992). This notion recently came into question when Pakistan objected to India's Kishanganga project; Pakistan decided to go straight to arbitration without considering the other options available under the Indus Water Treaty (Chintan 2011). This issue illustrates the difficulties with static water treaties, since conditions change over time and the countries concerned find that treaties become increasingly out of tune with the new conditions (Biswas 2011). Salehin et al. (2011) document the status of cooperation in the GBM basin. They conclude that the lack of mutual trust and confidence among the co-riparian countries has played a major role in the long-standing disputes or conflicts surrounding transboundary rivers.

A lack of trust between the countries combined with the absence of a shared vision has led to a pattern of non-cooperation in the region. As Biswas (2011: 669) notes, "This pernicious mind-set has eroded goodwill and confidence, and has generated mutual mistrust and suspicion. The situation is further compounded by the failure of the political leaders to create public opinion in favour of formulating and implementing a vision for regional cooperation and development". Studies on transboundary water conflict and cooperation generally consider interstate relations over shared water resources without also considering intrastate relations. International water conflict and cooperation may be influenced by domestic politics and vice versa (Giordano et al. 2002). For example, the failure of India and Bangladesh to reach an agreement on the proposed Teesta River Treaty in 2012 was a result of opposition by the state government of West Bengal.

The major problem lies in the lack of understanding or acceptance of mutual benefits in co-management of transboundary rivers. Sharing of water is based on parties who give and take water and therefore is largely understood a win-lose game. Promoting peaceful cooperation for environmental management, benefit-sharing and sustainable use of transboundary freshwater resources is possible only if innovative approaches are used that bring together all sectors and actors whose actions affect the transboundary water body at regional, national and local levels (Earle et al. 2010). The development of a science-based diagnostic analysis is essential to identify the threats to the transboundary ecosystem and to break down the issues into manageable parts with the aim of developing a strategic action programme. The sharing of benefits from water use - whether from hydropower, agriculture, flood control, navigation, trade, tourism or the preservation of healthy aquatic ecosystems - is immense and therefore a mindset shift is needed.

\subsubsection{The Future of Water Governance in South Asia}

The gap between the potential benefits of cooperating to develop and manage shared water resources and the reality of continuing poverty, food insecurity, energy insecurity and resource degradation is immense and growing. We offer a few suggested 
changes in governance arrangements that could lead to a more positive outcome by 2030 .

First, the "space" for regional water management must be redefined. Discussions and agreements on river water (or benefit) sharing must move from being bilateral to being multilateral: to date, most of the diplomatic initiatives on river water sharing have been bilateral in nature. Multilateral discussions, including recognition of local competition for equitable access to water, could reduce the dominance of any single state leading to more equitable and legitimate agreements. Second, South Asian governance arrangements need to adopt a "co-management" and "benefitsharing" perspective, rather than only sharing water. There is a dire need for comanagement of transboundary rivers for mutual benefit, especially as climate change and human interventions affect water flows. This will require a more diverse range of expertise and inclusion of a wider set of actors to succeed. Third, hydropower and the creation of an integrated South Asian power grid offer a gamechanging opportunity for regional prosperity and peaceful coexistence. The cooperation between Bhutan and India demonstrates the potential for such an integrated approach. Achieving such regional win-win partnerships by 2030 will be difficult but is not impossible. Achieving this game-changing state of affairs will require mobilising diverse types of expertise and facilitating the active engagement of multiple actors ("beyond disciplines"); changing mindsets from a hydrological to a problemshed paradigm ("beyond scales"); and implementing effective institutional arrangements while - most important - strengthening capacities for negotiation, dialogue and communication as well as technical skills and identifying effective champions with a regional vision ("beyond institutional hardware to human software"). Organisations operate in the manner they do as a result the behaviour of people who work within them (Senge et al. 2008). These steps will need to be accompanied by a process to create the institutional frameworks critical for long-term success.

\subsection{Southern Africa: A Glass Half Full?}

\subsubsection{The Regional Context}

Water resources are highly varied across Southern Africa. The region receives most of its water during the wet summer season (October to April), when rain arrives from the Indian Ocean. The majority of this water falls within $400 \mathrm{~km}$ of the east coast of the continent. In general, the region is better watered in the north and east and much drier in the south and west, except along the southern coasts of South Africa. According to Conley (1996: 17), "the Zambezi River carries more than ten times as much water, and the Zaire [Congo] River carries more than a hundred times as much water, as the Orange River in the south". In addition, the region is prone to both drought and flood, sometimes occurring simultaneously (Chenje and Johnson 1996: 2). While it is often said that Southern Africa is "water scarce", it should be 


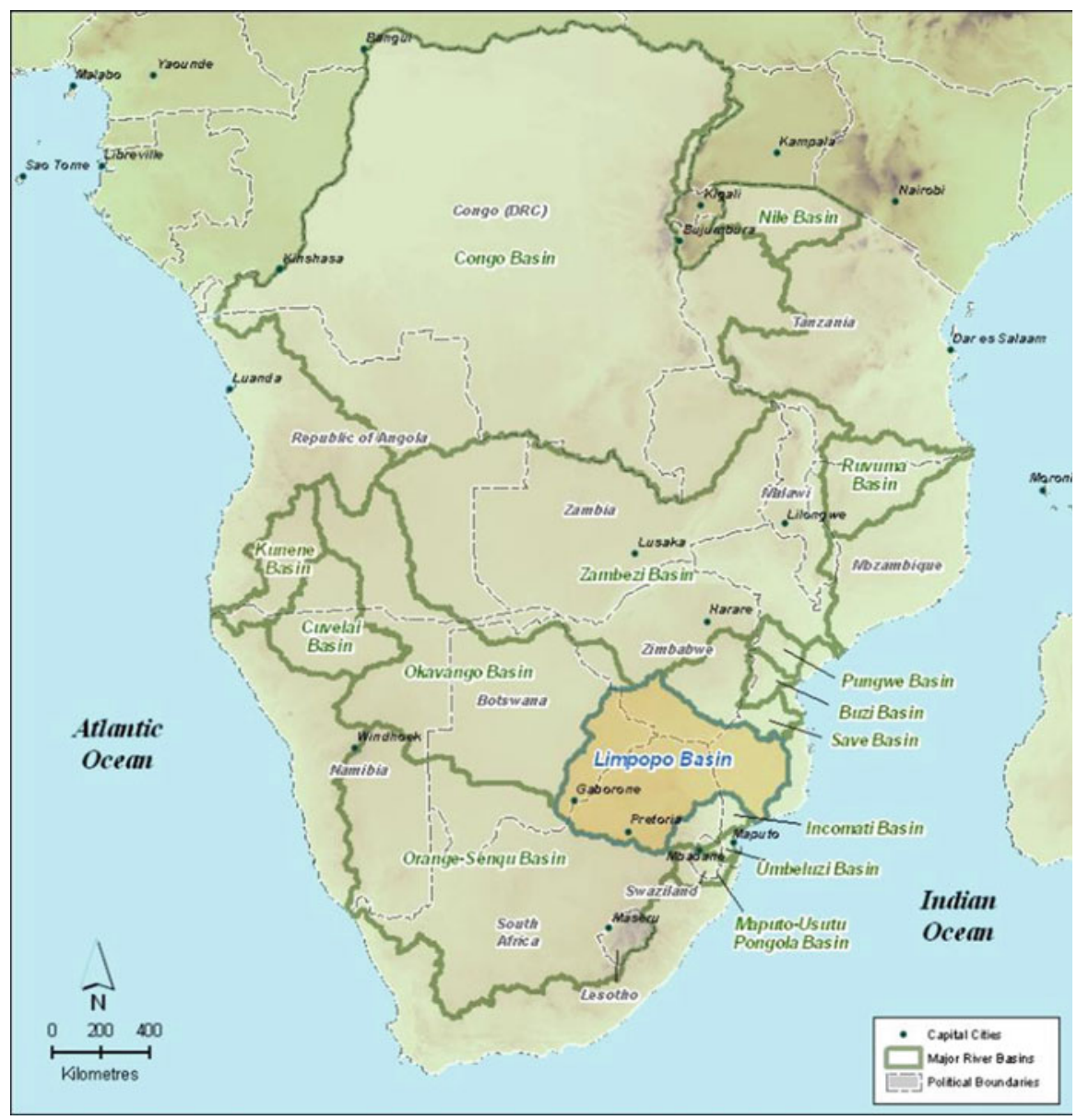

Fig. 12.2 Transboundary River Basins of SADC (Source: http://www.limpoporak.com/en/river/ geography/basins+of+southern+africa.aspx)

noted that scarcity is driven primarily by human and economic factors more than it is in terms any "water endowment". As shown in Fig. 12.2, there are at least 15 international watercourses in the SADC region (Swatuk 2002; Ashton 2002).

No community, country or region anywhere in the world began with effective water governance. Governance structures evolve over time as a consequence of need and as a reaction to a set of conditions relative to water in social relations. Their institutionalisation emerges over time. Rare is the institution that emerges fully blown; rather, what we see is the gradual build-up of a governance system over time. Even where new states are created, such as South Sudan, with new institutional arrangements, these will be infused with the pre-existing social norms, practices

${ }^{3}$ Ashton and Turton (2009) identify 21 basins. This is a debate we do not pursue here. 
and expectations that cannot be erased, but which may not be adequately acknowledged in a state-building process. Thus, as Dovers (2001) points out, institutions better reflect the past than anticipate the future. Given their histories, "[i]nstitutions are both barriers to and opportunities for ecologically sustainable human development. Institutions can pervert or empower human potential" (Dovers 2001: 215). Path dependency is real.

\subsubsection{Evolution of Regional Water Governance}

It has been more than 20 years since the Southern African Development Coordination Conference (SADCC) became the Southern African Development Community (SADC). With regard to water resource governance and management, SADC member states have been engaged in significant institution building, at national and regional levels, over the past two decades. All member states have or have expressed their intention to revise their water laws, to reform their governance arrangements and to create new water management organisations. Most have attempted to bring their national laws, policies and procedures into line with fellow member states, all of which are informed by the Revised SADC Protocol on Shared Watercourses (referred to as the "SADC Protocol" from here on), and dominant global discourses concerning integrated water resource management, water integrity and water efficiency, to name only three of the many conceptual influences active in the region. These initiatives are supported by a seemingly never-ending flow of people, finance, technology and ideas from Europe and elsewhere in the world. It is a rather grand experiment with uneven results (Swatuk and Fatch 2013).

These mixed results are understandable. This is especially so when one considers the failure to factor into plans, policies and programmes the historical basis and contemporary manifestation of the politics of water resource access and use in postcolonial/post-apartheid Southern Africa. Put differently, Southern Africa comprises a set of unevenly developed states where access to water and land reflects profound socio-economic inequalities. To shy away from these facts is to guarantee poor water governance. Thus, to say that a triple-E (social equity, economic efficiency, environmental sustainability) bottom line is the aim of national/regional water governance is simply not enough (SADC 2011, 2012). The region must move beyond high-minded platitudes to improve practices and achieve better outcomes. This requires asking difficult questions regarding the relationship between existing governance structures and management practices and their role in, and relationship to, abiding conditions of widespread poverty and unequal access to and economically and environmentally unsustainable use of water. As with South Asia, demographic drivers - urban population growth, abiding rural poverty - and extensively shared international waters should concentrate the minds of decision-makers, particularly under the speculative cloud of the negative impacts of climate change.

Many good things have happened over the past two decades. The legal basis is mostly in place regarding fair and equitable use of the region's resources, both 
within states and among them. Most of the region's shared basins have some sort of governing architecture in place. At the centre of regional cooperation is the SADC Protocol, without which many of the joint fact-finding and knowledge-building exercises in the region's basins may not have been possible. Dramatic changes in South Africa's political landscape since the early 1990s were initially accompanied by sweeping changes to that nation's policies, laws and institutions. South Africa became a very active member of SADC, leading processes around issue areas such as devising national water policies, strategies and laws. South Africa's water reform spurred the wave of reforms experienced in neighbouring countries post-1990 as well.

However, like many developing countries, SADC states struggle with implementing many of their well-formed policies, laws and procedures. There are a wide variety of explanations regarding this relatively poor performance: human, financial and technological shortages, "poor governance" embedded in unequal states, tensions around the creation of new sources of authority such as catchment management agencies or councils and water user associations, resource capture facilitated by neoliberal approaches to resource management and persistent global economic crises forcing resource-extracting economies to "stick to what they know". Some critics have argued that rather than introduce a whole new set of structures, state actors should have worked with existing, already legitimate, forms of authority. Van Koppen et al. (2014) suggest that the nationalisation of water resources and the introduction of formal permit systems, while probably important in principle (particularly in highly unequal societies), have in fact facilitated further resource capture by the empowered and the undermining of local systems of governance.

Yet there are success stories: Namibia's basin management committees, particularly in the western-draining ephemeral Kuiseb river basin, show the real potential for ideal-typical IWRM-style systems to emerge (Manning and Seely 2005). Indeed, the role of Rand Water, South Africa's largest water services provider in the Greater Johannesburg Metropolitan Area, suggests that public-private partnerships can work given a particular set of parameters ${ }^{4}$. In the transboundary context, states have shown a willingness to cooperate, though not quite extending to striking what Litfin (1997) describes as "sovereignty bargains", such as those that typify the European Union. New modalities of decision-making have been successfully introduced; numerous multidisciplinary, transnational research and knowledge-generating projects and programmes are underway; and the important 14-year-old regional water research and education programme, WaterNet ${ }^{5}$, has been building the region's professional capacity. WaterNet is recognised as the water capacity-building arm of SADC, and its implementation through a set of regional universities and training institutions has promoted mutual understanding - even friendships - among regional water professionals. To be sure, some of these activities are being pushed by external actors, whose absence would quite possibly threaten the negotiation and bargaining processes. Much of this feels like one step forward, one step backward, yet

\footnotetext{
${ }^{4}$ Rand Water is a government-owned entity that operates autonomously, largely like a private firm. ${ }^{5} \mathrm{http} / / / w w w . w a t e r n e t o n l i n e . o r g /$ (accessed 8 September 2015).
} 
if we are to realise the imagined sustainable water resource governance future of the region, it is important to see the glass as half full.

\subsubsection{How to Fill a Glass that Is Half Full}

A sustainable water governance future will require a firm technical and legal/institutional foundation, i.e. institutional hardware. But having adequate amounts of money, physical infrastructure (pipes and so on) and the right systems of delivery and oversight will only go so far in the absence of what we are calling "appropriate human software". In our view, one key element is leadership - at all levels. Even those who have advocated for the role of institutions above individuals have conceded, as noted for South Asia, that the behaviour of individuals within organisations determines the outcomes. Indeed, the importance of individuals to the success or failure of effective water governance is under-researched despite being critically important (Kranz and Jacobs 2012). The role of the individual in relation to skills audits and occupational profiles needed for effective water management has been analysed in several disciplinary-specific analyses, particularly in education science. However, these have centred on human resource assessments of technical qualifications and their alignment with professional job descriptions in water and wastewater treatment. More research needs to be conducted on the role of the individual in actively addressing complex water-related challenges, in redefining how multiple sectors cooperate around these issues, and ultimately influencing socio-economic development at the regional level.

Part of the problem with water governance in the SADC and indeed SAARC regions is that political and economic power confers water security as a right upon the office holder or private actor, and subsequently, those whom they deem worthy. In the days leading up to the end of colonial/apartheid rule and for several years thereafter, leaders in Zimbabwe, Namibia and South Africa took decisions as if time was short and the needs of all citizens mattered. These countries are now many years into "independence" and the urgency - as well as most of the leaders - has evaporated. In the cases of Zimbabwe, Angola and Mozambique, a fundamental problem is that there has been little or no turnover at the top of the ladder, draining the life out of the system, particularly at the lowest levels of authority. Where will the vision and drive come from when the need for change is least apparent to those ostensibly responsible for the task?

One way to accelerate development from a water perspective is to train leaders that can speak different (technically specific) languages and who can convey and convince a critical mass of the appropriateness of a particular intervention. This speaks both to the role and need for individuals who are able to adopt a broader and more holistic mindset. But it may also include the identification of particular occupational or personality profiles for transboundary managers and policy-makers who are more predisposed to operate in this socially constructed landscape. 
To build the necessary human software and to inhabit the existing institutional hardware, education matters. Present and future generations of leaders must be made to see that water is not an ordinary good (Savenije 2002). Since water infuses all things and is fundamental to the functioning of all elements of society, it must be mainstreamed throughout the region's information and educational systems. What should be avoided is the "crisis narrative" - though to be sure, there is a crisis and it is felt primarily by the poor - and what should be showcased is how everyone is downstream. Put differently, poor and misguided behaviour will eventually come back to haunt you. No matter how insulated political and economic leaders and their families feel, they are only one tweet away from ending up like Egypt's Hosni Mubarak. The growing number and seriousness of social protests around water supply delivery in South Africa, which has also become an important political issue, is an indicator of the danger.

Trust - social capital - also matters. Good governance depends upon state-civil society relations wherein state action acts as a feedback loop to civil society expectations. Every opportunity must be taken to draw political leaders into activities where political involvement is necessary to facilitate project or programme success. For example, in Botswana, President Ian Khama's role as patron of the Kalahari Conservation Society ensures environmental issues a place of importance at the highest levels of decision-making. Of course, such interactions should also acknowledge the existence of power relations, i.e. how individuals interact with each other and absorb information. If one actor is perceived to be powerful, other people in the conversation may feel too intimidated to speak. This dynamic needs to be carefully managed to foster fruitful dialogue. This point is particularly relevant for policymakers operating at the regional level who have to contend with different levels of power purely as a result of where they come from, i.e. with some countries being more able to influence policy decisions because of socio-economic clout, military hegemony, human capacity and/or influential alliance. Where progressive systems are already in place, such as much of the SADC region, leadership and ethics must be one focus for filling a half-filled glass.

At the 2012 International Freshwater Conference, a question was asked in plenary on whether the push for basin-scale governance structures wasn't a mistake and that perhaps it made more sense to work from existing structures and imbue them with a "river basin sensibility". The panel, comprising senior government officials and former members of the water administration, was uniformly in agreement: the basin is the way forward. If this is the case, then perhaps we can approach the question in the opposite way: with a river basin governance framework in place, is it not important to (i) embed this level of authority within existing levels of authority in meaningful ways and (ii) imbue the river basin authority with a sense that water itself is highly fluid, moving in and out of the basin in a variety of forms (e.g. as virtual water) impacting a wide variety of actors, themselves external to the basin? What we are suggesting is a type of governance framework that emerges through a process Cleaver $(2002,2012)$ describes as bricolage: building on existing structures rather than creating new ones that may be regarded as a threat to existing authorities (Jonker et al. 2010; Merrey and Cook 2012). It has been suggested that river basin 
governance would be more effective if the higher level institutions incorporated basic values and processes characterising local indigenous governance (Merrey 2009). In any event, it is clear that the new basin management regimes within states have stalled for this very reason. Future water governance will have to be flexible enough to draw in participants when needed; this will be a kind of networked governance not solely dependent upon the physical geography of the river basin.

Lastly, we wish to highlight the value and importance of moving beyond the water sector and beyond the pride of place held by physical/environmental scientists: engineers, hydrogeologists, biochemists and so on. Some years ago, Turton et al. (2007) described the importance of the government-science-society "trialogue". Sustainable, equitable and efficient water governance will also require unpacking "science" to ensure that political, social and even philosophical/ethical dimensions are adequately captured. Most water problems are self-inflicted: they result from human interventions into natural processes, affecting the hydrological cycle among other ecosystem dynamics. People as groups and individuals are affected differently and therefore regard particular outcomes of these activities very differently. Decisions regarding use and management therefore are imbued with normative, ethical and subjective considerations. The questions asked, the problems addressed and the "experts" drawn upon reflect the particular constellations of forces that exist within a society at any one time (Swatuk 2010). It is imperative, therefore, that future water governance arrangements make adequate space for contested ideas and interests and the ways and means of accommodating these without violence. Many of the necessary elements are in place in the SADC region. The challenge, then, is to fill the glass, not draw down the fluid that is already there.

\subsection{Conclusion: Prospective Futures of Water Resource Management}

At present, governance structures, organised nationally and transnationally on a basin scale in both regions, presume that "stakeholders" can adequately represent themselves in formal settings where allocation, use and management decisions are taken. This is problematic in at least three ways. The first is where rural areas are divided in terms of large-scale, cash crop producers and small-scale producers (Southern Africa) or in terms of wealthy expanding urban centres and small-scale producers (South Asia). The former are few but economically and politically powerful. The latter are many, but poorly empowered, especially where water and land allocation and use decisions are concerned. The former commandeer the vast majority of blue water for irrigation or urban and industrial uses. The latter farm the worst land and depend heavily on the green water flow deriving directly from rainfall. The second is in urban areas divided between the rich few and the many poor. The former have in-house provision "on tap" and are able to supplement shortages in many ways. The latter often depend on on-plot or communal standpipes that may not be working or working only intermittently. The former have access to water-borne 
sewerage systems that are well serviced. The latter make do with an array of often quite alarming "options". Where resource-poor municipalities are forced to make choices, they have opted for privatising systems of delivery which too often reinforce the existing inequalities, delivering too little of poor quality to the urban poor. And the third is that dominant narratives and framing concepts such as "climate change-induced scarcity" and "closed basins", to name but two, reinforce path dependencies, as the "haves" aim to hold onto what they have and to extend their water "rights" where possible (e.g. with large farmers shifting into "biofuels" as a means of extending holdings and profits). Taken together, if left unattended, these three factors will not only reinforce social inequity, economic inefficiency and ecological unsustainability; they also heighten the likelihood of conflict among "stakeholders" at a wide variety of scales: within the state, within the city, across the countryside and across state borders.

In other important ways, especially at the transnational level, South Asian and Southern African water governance arrangements are on what seem to be different trajectories. In South Asia, the governance glass is not only half empty but is not filling up. In Southern Africa, the governance glass is half full and there are prospects - though no guarantee - it will be fuller by 2030. Both regions have a regional association to promote cooperative development, the South Asia Association for Regional Cooperation (SAARC) and SADC. However, the SAARC website (http:// saarc-sec.org $/^{6}$ ) does not refer to cooperation in management of water resources, while SADC has provided a forum for its members to agree on governance arrangements for shared water resources. In addition to the SADC Protocol, there are regional water strategies and plans as well as increasingly effective joint commissions for managing each of the major shared river basins. Both regions are dominated by countries with a British colonial past (though SADC has two Lusophone countries). While it is true that SADC's scale in terms of area and population (approximately 250 million) is a fraction of South Asia's, SADC does have more member countries (15); and although the river basins are smaller, there are more of them and most are "closed" - there is no more water to be allocated. Scale alone cannot explain their contrasting trajectories.

While more work would be needed for a full analysis of the roots of their differences, we suggest that their different histories - and not scale or ecology - explain their divergence. Here we discuss four factors: (1) the contrasting roles of the hegemonic power, (2) the different levels of "trust", (3) the roles of civil society and other NGOs and (4) the roles of external facilitators.

Until the end of apartheid in the early 1990s, South Africa was at odds politically with most of its neighbours and regional countries. It did strike bilateral agreements for management or development of specific river basins, using its overwhelming power to ensure it got a good deal. After 1994, South Africa adopted a policy of collaboration with other countries in the region. It plays a critical role in driving the process of increasing regional partnerships through SADC in a wide variety of sectors, not only water. SADC can be seen as an example of expansion from a narrow

\footnotetext{
${ }^{6}$ Accessed 8 September 2015.
} 
river basin focus to a broader shared social basin or "problemshed" perspective. Nevertheless, we cannot push this point too far: concerns about South Africa's intentions have been one factor retarding the development of the Limpopo Watercourse Commission (LIMCOM). South Africa is not a riparian on the largest regional basins, the Congo and Zambezi, where cooperation remains problematic; however, it does have a strong interest in expanding their hydroelectric potential. ${ }^{7}$ Agreements on how best to manage the Zambezi water resources will be a defining factor for regional development by 2030 (Swain et al. 2011).

In South Asia, the long-standing conflict between India and Pakistan overshadows all efforts to promote regional cooperation. In addition, India has never tried to play the role of the "benign hegemon" that South Africa deliberately tries to play; its role is more analogous to that of apartheid South Africa. India finds it difficult to share data and to support efforts to create governance structures that would enable shared development and management of water resources for mutual benefits. These differing roles may in part be a product of how local (i.e. within-country) water issues affect transboundary cooperation in South Africa and India. In India, states have considerable constitutional and political power over water development - and the country has struggled to resolve interstate conflicts. As the Teesta river case shows, Indian states can even veto international agreements. This cannot happen in South Africa: water resources are constitutionally and politically a central government subject; and the provinces are relatively weak entities. A critical determinant of the shape of water resource management by 2030 will be India's role.

Related to this contrast in the role of the hegemon is the question of trust. Given the long history of apartheid in Southern Africa, it may seem surprising that the level of intercountry trust is higher than in South Asia. This is not universal Mozambique is wary of the actions of its upstream neighbour South Africa, for example. Nevertheless, the seemingly interminable workshops and meetings at multiple levels, many facilitated by the regional Global Water Partnerships (GWP), have contributed greatly to creating a large degree of mutual understanding and strong personal relationships among civil servants, water professionals and civil society members ${ }^{8}$. Another major contributing factor is the role of WaterNet, a network of over 65 universities and training and research institutions with capacities in water management training and research. Through its professional interdisciplinary M.Sc. course, regional professionals spend time in other regional countries and develop strong personal ties as they work and study together; and regional institutions develop strong professional partnerships. The net result of the many regional workshops and joint training and research programmes is a cadre of professionals that combine "soft" skills with professional competence, linked into an effective personal network. These activities rest on a shared history of resistance to colonial rule and apartheid oppression. Put differently, the long history of warfare in the

\footnotetext{
${ }^{7}$ There are also speculative plans to divert Zambezi water south to South Africa, though this seems unlikely to happen.

${ }^{8}$ These are incidentally found at the highest level as well, as the leaders of some of the countries in the region had strongly supported the African National Congress when it was fighting apartheid.
} 
region has helped strengthen interstate relations - an important foundation for facing shared current (e.g. drought/flood) and future (e.g. climate change-induced hydrological extreme variability) challenges. South Asia's history is quite different.

In South Asia, long-standing unresolved conflicts continue to dominate. Pakistan was carved from the eastern and western wings of British India in bloodshed; Bangladesh was created in a bloody civil war that involved India; and India is concerned about the influence of China on its neighbours. SAARC remains a weak entity, unable to overcome the mutual suspicions characterising relationships among the member countries. Civil society initiatives such as the SaciWATERS (South Asia Consortium for Interdisciplinary Water Resources Studies) initiative called "Crossing Boundaries" have brought some researchers in South Asian universities together. However, there are far fewer regional workshops and meetings (including World Bank's South Asia Water Initiative) than in Southern Africa - in part because of travel restrictions between Pakistan and India. The regional GWP is less effective than in Southern Africa; it lacks the convening power GWP-Southern Africa has earned. There is no equivalent of WaterNet.

This leads to the third significant factor: the roles of civil society organisations and regional NGOs. While within South Asian countries (especially India, Bangladesh and Nepal) civil society organisations have strong voices in the water sector, there are no effective NGOs working on South Asian regional water issues outside the GWP, and its convening power is weak. In Southern Africa, there are a number of regional NGOs with strong convening power. Examples include not only GWP-Southern Africa, but also the Food, Agriculture and Natural Resources Policy Analysis Network (FANRPAN). These organisations have teamed up, for example, on the Limpopo Basin and have also drawn in some of the key national NGOs and civil society organisations.

Finally, the fourth factor is the role of outside facilitators - especially donors. In Southern Africa, a number of European donors have played key roles not only in facilitating communication and agreements but in financing their implementation. This applies as well to WaterNet, FANRPAN and GWP. Indeed, these donors are so critical that they seem to have created a dependency on outside funding. If they suddenly withdrew, it is not clear how sustainable the regional water governance institutions would be. Nevertheless, without their support Southern Africa would not have reached its current level of cooperation and partnership, which importantly includes streamlining water-specific legal and institutional frameworks across the region, as well as building local and national capacity for such things as improved urban water supply, rural (economic and household) water provision and environmental management.

Donors have to date not been able to play such a significant facilitating role in South Asia, perhaps in part because of Indian resistance. We argue that in regions with long histories of conflict, having such an outside facilitator cum financier in the initial stages is crucial. The Nile and Mekong river basins are cases in point.

However, in addition to creating dependency, the donors may have retarded infrastructural development in Southern Africa. The donors have at times made 
IWRM an end in itself, at the expense of implementing practical solutions (Giordano and Shah 2014). With their emphasis on environmental conservation and high levels of consultation with all stakeholders - driven by internal constituencies - they have been reluctant to finance major infrastructural development in the water sector beyond local water-supply systems.

Will the water resource glasses be fuller by 2030 than they are now? Both regions could benefit from regional cooperation based on sharing the benefits of water resource development, for example, through regional electricity networks. The prospects seem good in Southern Africa, if the countries can move from talking to investing and creating a more integrated regional economy based in part on shared management of water resources. The potential is great but prospects are less rosy in South Asia: there are growing challenges internally in providing water and power services. These could be addressed through effective regional cooperation. But without stronger regional networks, partnerships and institutions supported by external facilitators, South Asia may fail to take full advantage if its water resources to achieve better lives for its people by 2030 .

Acknowledgements Anjal Prakash acknowledges the support received from the Asia Foundation to the project - Transnational Dialogue for Improved Water Governance of Brahmaputra River (http://www.saciwaters.org/brahmaputra-dialogue/) that facilitated his writing.

\section{References}

Ahmad, Q. K., Biswas, A. K., Rangachari, R., \& Sainju, M. M. (Eds.). (2001). GangesBrahmaputra-Meghna region: A framework for sustainable development. Dhaka: The University Press Limited.

Ahmed, S. (2008). Gender and integrated water resources management in South Asia: The challenge of community-based alternatives. In K. Lahiri-Dutt \& R. Wasson (Eds.), Water first. Issues and challenges for nations and communities in South Asia (pp. 185-206). New Delhi: Sage.

Aquastat. (2011). Ganges-Brahmaputra-Meghna River basin. Food and Agriculture Organization of the United Nations. http://www.fao.org/nr/water/aquastat/basins/gbm/index.stm. Accessed 11 Mar 2014.

Ashton, P. J. (2002). Avoiding conflicts over Africa's water resources. Ambio, 31(3), 236-242.

Ashton, P., \& Turton, A. (2009). Chapter 50: Water and security in sub-Saharan Africa: Emerging concepts and their implications for effective water management in the Southern African region. In H. G. Brauch, U. O. Spring, J. Grin, C. Mesiasz, P. Kameri-Mbote, N. C. Behera, B. Chourou, \& H. Krummenacher (Eds.), Facing global environmental change (pp. 661-674). New York: Springer, Berlin.

Bevir, M. (2013). Governance: A very short introduction. Oxford: Oxford University Press (quoted in Wikipedia). http://en.wikipedia.org/wiki/Governance

Biswas, A. K. (1992). Indus water treaty: The negotiating process. Water International, 17(4), 201-209.

Biswas, A. K. (2011). Cooperation or conflict in transboundary water management: Case study of South Asia. Hydrological Sciences Journal, 56(4), 662-670.

Bizikova, L., Roy, D., Swanson, D., Venema, H. D., \& McCandless, M. (2013). The water-energyfood-security nexus: Towards a practical planning and decision-support framework for land- 
scape investment and risk management. IISD Report (February). http://www.iisd.org/pdf/2013/ wef_nexus_2013.pdf

Briscoe, J., Qamar, U., Contijoch, M., Amir, P., \& Blackmore, D. (2005). Pakistan's water economy: Running dry. Washington, DC: The World Bank.

Burton, A. (2011, April). Mun River dam demands Mekong rethink. Frontiers in Ecology and the Environment, 9(3), 145. Published by Ecological Society of America. http://www.jstor.org/ stable/41149732

Chenje, M., \& Johnson, P. (Eds.). (1996). Water in Southern Africa. Harare/Maseru: SARDC/ SADC.

Chintan, S. G. (2011). Transboundary river basins in South Asia: Options for conflict resolution. International Rivers. http://www.internationalrivers.org/files/attached-files/transboundaryriverbasins.pdf. Accessed 30 Mar 2014.

Cleaver, F. (2002). Reinventing institutions: Bricolage and the social embeddedness of natural resources management. European Journal of Development Research, 14(2), 11-30.

Cleaver, F. (2012). Development through bricolage: Rethinking institutions for natural resources management. London: Routledge.

Conley, A. (1996). A synoptic view of water resources in Southern Africa. In Solomon, H. (Ed.), Sink or Swim? Water, resource security and state co-operation. IDP Monograph Series No. 6. Pretoria: Institute for Security Studies.

Dovers, S. (2001). Institutional barriers and opportunities: Processes and arrangements for natural resources management in Australia. Water Science and Technology, 43(9), 215-226.

Earle, A., Jagerskog, A., \& Ojendal, J. (Eds.). (2010). Transboundary water management: Principles and practice. London: Earthscan.

Giordano, M., \& Shah, T. (2014). From IWRM back to integrated water resources management. International Journal of Water Resources Development, 30(3), 364-376. doi:10.1080/0790062 7.2013.851521.

Giordano, M., Giordano, M., \& Wolf, A. (2002). The geography of water conflict and cooperation: Internal pressures and international manifestations. The Geographical Journal, 168(4), 293-312.

Gopakumar, G. (2012). Transforming urban water supplies in India. London: Routledge.

Grey, D., \& Sadoff, C. W. (2007). Sink or swim? Water security for growth and development. Water Policy, 9(6), 545-571.

Grumbine, R. E., Dore, J., \& Xu, J. (2012). Mekong hydropower: Drivers of change and governance challenges. Frontiers in Ecology and the Environment, 10(2), 91-98.

Houba, H., Kim, H. P. D., \& Xueqin, Z. (2013). Saving a river: A joint management approach to the Mekong River Basin. Environment and Development Economics, 18, 93-109.

Jacobs, I. (2012). The politics of water in Africa: Norms, environmental regions and transboundary co-operation in the Orange-Senqu and Nile Rivers. New York: Continuum Books.

Jairath, J. (1999). Participatory irrigation management: Experiments in Andhra Pradesh. Economic and Political Weekly, XX(13), A-2-10.

Jonker, L. E., Swatuk, L. A., Matiwane, M., Mila, U., Ntloko, M., \& Simataa, F. (2010). Exploring the lowest appropriate level of water governance in South Africa (WRC report no. 1837/1/10). Pretoria: Water Research Commission.

Joshi, D. (2014). Women, water, caste and gender: The rhetoric of reform in India's drinking water sector. In V. Narain, C. G. Goodrich, J. Chourey, \& A. Prakash (Eds.), Globalization of water governance in South Asia (pp. 35-52). New Delhi: Routledge.

Kranz, N., \& Jacobs, I. (2012). Leadership capacity in transboundary basins: The interface between institutions and individuals. In D. Gallagher, N. Christensen, \& P. Andrews (Eds.), Environmental leadership: A reference handbook. Thousand Oaks: Sage. ISBN-10: 1412981506, ISBN-13: 978-1412981507.

Kulkarni, S. (2014). Gender, water and well-being. In V. Narain, C. G. Goodrich, J. Chourey, \& A. Prakash (Eds.), Globalization of water governance in South Asia (pp. 19-34). New Delhi: Routledge. 
Lahiri-Dutt, K. (2008). Introduction: Placing water first. In K. Lahiri-Dutt, \& J. Wasson (Eds.), Water first. Issues and challenges for nations and communities in South Asia (pp. I-xlix). New Delhi: Sage.

Litfin, K. T. (1997). Sovereignty in world ecopolitics. Mershon International Studies Review, 41(2), 167-204.

Lutz, A. F., \& Immerzeel, W. W. (2013). Water availability analysis for the Upper Indus, Ganges, Brahmaputra, Salween and Mekong River Basins - Final report. Future Water Report 127. http://www.futurewater.nl/wp-content/uploads/2013/10/FW_Final_Report_submitted.pdf

Manning, N., \& Seely, M. (2005). Forum for Integrated Resources Management (FIRM) in ephemeral basins: Putting communities at the centre of the basin management process. Physics and Chemistry of the Earth, 30(11-16), 886-893.

Mathur, K. (2009). From government to governance: The Indian experience. New Delhi: National Book Trust.

Merrey, D. J. (2009). African models for transnational river basin organisations in Africa: An unexplored dimension. Water Alternatives, 2(2), 183-204. www.water-alternatives.org

Merrey, D. J., \& Cook, S. (2012). Fostering institutional creativity at multiple levels: Towards facilitated institutional bricolage. Water Alternatives, 5(1), 1-19. www.water-alternatives.org

Mollinga, P. P. (2008). Water, politics and development: Framing a political sociology of water resources management. Water Alternatives, 1(1), 7-23.

Mollinga, P. P., Dixit, A., \& Athukorala, K. (2006). Integrated water resources management: Global theory, emerging practice, and local needs (Water in South Asia, Vol. 1). New Delhi: Sage.

Mollinga, P., Meinzen-Dick, R. S., \& Merrey, D. J. (2007). Politics, plurality and problemsheds: A strategic action approach for agricultural water resources management reform. Development Policy Review, 25(6), 699-719.

Narain, V. (2008). Crafting institutions for collective action in canal irrigation: Can we break the deadlocks? In V. Ballabh (Ed.), Governance of water: Institutional alternatives and political economy (pp. 159-173). New Delhi: Sage.

Narain, V. (2014). Whose land? Whose water? Water rights, equity and justice in a peri-urban context. Local Environment; The International Journal of Justice and Sustainability. doi:10.10 80/13549839.2014.907248.

Narain, V., Shah Alam Khan, A., Sada, R., Singh, S., \& Prakash, A. (2013). Urbanization, periurban water security and human well-being. A perspective from four South Asian cities. Water International, 38(7), 930-940.

Narain, V., Goodrich, C. G., Chourey, J., \& Prakash, A. (Eds.). (2014). Globalization of water governance in South Asia. New Delhi: Routledge.

North, D. C. (1995). The new institutional economics and third world development. In J. Harriss, J. Hunter, \& C. M. Lewis (Eds.), The new institutional economics and third world development (pp. 1-13). London: Routledge.

Parthasarathy, R. (1998). Reforms in irrigation management: Bottoms-up vs. top-down models (GIDR working paper no. 104). Ahmedabad: Gujarat Institute of Development Research.

Prakash, A., Singh, S., Goodrich, C. G., \& Janakarajan, S. (2012). Introduction: An agenda for pluralistic and integrated framework for water policies in South Asia. In A. Prakash, S. Singh, C. G. Goodrich, \& S. Janakarajan (Eds.), Water resources policy in South Asia (pp. 1-16). New Delhi: Routledge.

Prakash, A., Singh, S., \& Goodrich, C. G. (Eds.). (2013). Informing water policies in South Asia. New Delhi: Routledge.

Rogers, P., \& Hall, A. W. (2003). Effective water governance (Global Water Partnership Technical Committee (TEC) paper no. 7). Stockholm: GWP.

SADC (Southern African Development Community). (2011). Regional strategic action plan on integrated water resources development and management (2011-2015). December 2011. SADC, Gaborone.

SADC (Southern African Development Community). (2012). Regional infrastructure development master plan, water sector plan. Gaborone: SADC.

Sadoff, C., \& Grey, D. (2002). Beyond the river: The benefits of cooperation on international rivers. Water Policy, 4(5), 389-403. 
Salehin, M., Shah Alam Khan, M., Prakash, A., \& Goodrich, C. G. (2011). Opportunities for transboundary water sharing in the Ganges, the Brahmaputra and the Meghna Basin. In India infrastructure report 2011, Oxford Publication, pp 29-43. http://www.idfc.com/pdf/report/2011/ Chp-3-Opportunities-for-Trans-bounday-Water-Sharing.pdf

Saleth, R. M. (1996). Water institutions in India: Economics, law and policy. New Delhi: Institute of Economic Growth, Commonwealth Publishers.

Savenije, H. H. G. (2002). Why water is not an ordinary good, or why the girl is special. Physics and Chemistry of the Earth, 27, 741-744.

Senge, P. M., Smith, B., Kruschwitz, N., Laur, J., \& Schley, S. (2008). The necessary revolution: How individuals are working together to create a sustainable world. New York: Crown Publishing Company.

Shah, T. (2009). Taming the anarchy: Groundwater governance in South Asia. Washington, DC: RFF Press.

Shah, T. (2013). Climate change and groundwater: India's opportunities for mitigation and adaptation. In A. Prakash, S. Singh, C. G. Goodrich, \& S. Janakarajan (Eds.), Water resources policies in South Asia (pp. 213-243). New Delhi: Routledge.

Shah, T., \& Van Koppen, B. (2006). Is India ripe for integrated water resources management? Fitting water policy to national development context. Economic and Political Weekly, 41, 3413-3421.

Swain, A., Swain, R., Themner, A., \& Krampe, F. (2011). Climate change and the risk of violent conflicts in Southern Africa. Pretoria: Global Crisis Solutions.

Swatuk, L. A. (2002). The new water architecture in southern Africa: Reflections on current trends in the light of "Rio +10". International Affairs, 78(3), 507-530.

Swatuk, L. A. (2010). The state and water resources development through the lens of history: A South African case study. Water Alternatives, 3(3), 521-536. www.water-alternatives.org

Swatuk, L. A. (2012). Water and security in Africa: State-centric narratives, human insecurities. In M. Schnurr \& L. A. Swatuk (Eds.), Natural resources and social conflict: Towards critical environmental security (pp. 72-96). New York: Palgrave Macmillan.

Swatuk, L. A., \& Fatch, J. (2013). Water resources management and governance in Southern Africa: Toward regional integration for peace and prosperity. Global Dialogue, 15(2) (SummerAutumn). http://www.worlddialogue.org/content.php?id=564

Turton, A. R., Hattingh, H. J., Maree, G. A., Roux, D. J., Claassen, M., \& Strydom, W. F. (Eds.). (2007). Governance as a trialogue: Government-science-society in transition. Berlin: Springer.

Urs, K., \& Whittel, R. (2009). Resisting reform: Water profits and democracy. New Delhi: Sage.

Van Koppen, B., Van der Zaag, P., Manzungu, E., \& Tapela, B. (2014). Roman water law in rural Africa: The unfinished business of colonial dispossession. Water International, 39(1), 49-62. doi:10.1080/02508060.2013.863636.

WEF (World Economic Forum). (2011). Global risks 2011 (6th ed.). Cologne/Geneva: WEF.

Wirkus, L. (Ed.). (2005). Water, development and cooperation - comparative perspective: Euphrates-Tigris and Southern Africa (Bonn International Centre for Conversion (BICC) Paper 46). Bonn: BICC.

Wolf, A. T. (1998). Conflict and cooperation along international waterways. Water Policy, 1, 251-265.

Open Access This chapter is distributed under the terms of the Creative Commons AttributionNoncommercial 2.5 License (http://creativecommons.org/licenses/by-nc/2.5/) which permits any noncommercial use, distribution, and reproduction in any medium, provided the original author(s) and source are credited.

The images or other third party material in this chapter are included in the work's Creative Commons license, unless indicated otherwise in the credit line; if such material is not included in the work's Creative Commons license and the respective action is not permitted by statutory regulation, users will need to obtain permission from the license holder to duplicate, adapt or reproduce the material. 